\title{
Existential aspects in modern education
}

\author{
Tair M. Makhamatov ${ }^{1,2 *}$, Valeriy S. Khaziyev ${ }^{3}$, Timour T. Makhamatov ${ }^{1}$, Radik Z. \\ Yulbayev $^{4}$, and Lucio Giuliodori ${ }^{5}$ \\ ${ }^{1}$ Financial University under the Government of the Russian Federation, Department of Humanities \\ Science, Moscow, Russia \\ ${ }^{2}$ Professor of the Diplomatic Academy of the Ministry of Foreign Affairs of the Russian Federation, \\ Moscow, Russia \\ ${ }^{3}$ Bashkir State Pedagogical University named after M. Akmulla, Faculty of Philosophy, Sociology \\ and Political Science of the Institute of History and Law of M.Akmulla, Ufa, Russia \\ ${ }^{4}$ Bashkir State Pedagogical University named after M. Akmulla, Institute of Spiritual Security and \\ Development of Religious Education, Ufa, Russia \\ ${ }^{5}$ Peoples' Friendship University of Russia, Agrarian-Technological Insitute, Faculty of Foreign \\ Languages, Moscow, Russia
}

\begin{abstract}
The authors analyse the current objectives of modern education, based on recent studies of human existence revealing its multidirectional and multifaceted nature and determining the life position and behaviour of a person. The levels of the modern education system often do not focus on the existential aspect because of the educational goals and objectives, which is to prepare the workforce for the labour market. The transformation of the negative form of a student's existence into the existence of a person struggling with the absurdity and meaninglessness of life is not included in the educational process. The authors propose an original way of solving this urgent problem of modern education. The research methodology is based on the concepts introduced by M. Gordon, S. Bakewell, T. Staehler, and V.V. Varava about the possibility of using the "dark aspects" of existence as a source for personal development. Besides, the concept developed by T.M. Makhamatov about the multidirectional phenomena of existence has been used to analyse the problem. The authors conclude that today, the education system focuses not only on high professionalism among students but also on such existential aspects as Sisyphean dedication and determination, as well as the ability to deal with meaninglessness, absurdity, anxiety, and fear and the ability to turn them into a source for self-affirmation. It is possible to implement this task by developing such an ability to overcome the absurdity of human interaction with external being, as Sisyphean labour, as a search for meaning in something meaningless.
\end{abstract}

Keywords: educational objectives, existence, Sisyphean hill, personal development.

\footnotetext{
* Corresponding author: makhamatov.tair@mail.ru
} 


\section{Introduction}

Education is an important process of human socialization. It is the formation and definition of one's inner world and, which is also important, its existential content. The existential aspect of education is basic since it affects human subjectivity and the inner world. However, the existential aspect of the educational crisis is not limited to the "meaninglessness of education" from the point of view of the individual as the main subject of education [1:304]. There is no human without existence, which can be manifested in different forms and focuses; it can be positive, negative, aggressive, nihilistic, or optimistic [2-5]. One of the main problems and challenges of modern education, along with training a highly qualified specialist, is the formation of an optimistic form of existence. The present research is aimed to define the essence of such existence.

\section{Methods}

The research methodology was determined by one of the main features of existentialism, namely, its evolution form. Its appearance is associated mainly with Russian literature and F.M. Dostoevsky in particular, who is considered to be its originator. Existentialism as a form of philosophical inquiry was presented by S. Kierkegaard, followed by J.-P. Sartre, A. Camus, K. Jaspers, M. Heidegger, etc. However, the way of exploring the inner moral and psychological world through literature, introduced by J. Malpas in his studies, turned out to be the most adequate form of expression and evolution of existentialism [6]. The inner world of a person, who suffers and looks for the reason for existence in life contradictions, was adequately reflected in the works by F.M. Dostoevsky, J.-P. Sartre, A. Camus, K. Hamsun, $\mathrm{Ch}$. Aitmatov, etc. These works became the basis for the research methodology.

In the given work, we relied on the research by V. Varava [5], M. Ryumina, [1], Marino Gordon [3], Sarah Bakewell [7], Tanja Staehler [8-10], and several 2017-2020 publications in the British magazine "Philosophy Now" in the field of analysis of the characteristics of human existence in modern times. In this work, we used the methodology developed by T.M. Makhamatov concerning the multidirectional phenomena of existence and the concept of finding "the top of Sisyphean hill".

\section{Results and discussion}

The objectives, features, content, and teaching methods in the education system determine the formation and evolution of a person's existence.

The objective and historical process of globalization and the unformed tendency of private entrepreneurship in young liberal-democratic societies have a double-edged impact on the educational process. On the one hand, the material and financial support of all levels of the education system is increasing. This has a positive impact on the employment of university graduates.

On the other hand, the top priority of the education system becomes the preparation of the workforce instead of the development of a person with a rich spiritual culture and a progressive worldview, who is ready to fight injustice and life challenges [11]. The graduates become products for the labour market. Bearing in mind the fact that professions quickly become outdated, yesterday's graduates become people suffering from precarity. From the beginning, their existential worldview is formed with anxiety and uncertainty in the future. According to M.S. Ryumina, "the uncertainty in value and ideological orientations makes people consider any form of activity to be meaningless" [1:306].

The inner world of a person, as known since the publication of the results of research by Sigmund Freud, inevitably contains a contradiction between rationality and irrationality. 
Humans remain dominated by irrationality although they are social beings and their existence is not connected with the ability to think, as it was stated by Descartes: "I think, therefore I am". The idea of the meaninglessness of a person's activities, the uncertainty in future, and the absurdity of the environment reinforce the irrationality and intensify the pressure of the "dark matters" of existence, such as anxiety, depression, despair, and death [3: 122].

Another source for existentialism is the contradictions, misunderstandings, and unacceptability of other people that constantly arise at all stages of socialization. According to A. Camus, "It is probably true that a man remains forever unknown to us and that there is in him something irreducible that escapes us" [12:228]. These contradictions are aggravated by the increased flow of refugees and labour immigrants and the crisis between white people and people of colour.

In the context of such a complex socio-psychological situation, the education system faces a difficult philosophical task to find ways to bring together all forms and aspects of existentialism and create a unified system based on searching for meaning in something meaningless and hope in something hopeless [8, 13]. Following Marino Gordon, one can try to identify ways to reorient the "dark matters" of existence for the sake of self-development, the result of which would be the bright future [3: 122].

We see the solution to the problem in "Sisyphean labour", which is rolling a boulder up a hill, being punished by the gods. The attitude of Sisyphus to his meaningless punishment can be considered an attempt to overcome the meaninglessness of his labour, maintaining hope in a hopeless action, and, therefore, heroism. Indeed, even realizing that the boulder will roll down, Sisyphus repeats this action. A person, according to A. Camus, derives from the contradictions and the absurdity of life "the reasons for believing, reasons for hoping from his fecund despairs, and calling life his terrifying apprenticeship in death" [4: 404]. People must understand that they have their own "Sisyphean hill" and must be prepared for the "Sisyphean labour".

Another form of the existential struggle with the "dark matters of existence", as M. Gordon put it, is Calvary, where Jesus was crucified. The Son of God fears death and suffers as a human, but he understands that he atones for the sins of mankind by his suffering and human death. Jesus, being the Son of God, could limit himself to his sermons, or, in other words, to a rational way to set humanity on the Path of Truth. Yet, he chooses the irrational way and deserves the Resurrection because of his suffering, patience, and faith in the righteousness of the decision of God the Father.

The formation of the idea that the life of every person is a "Sisyphean labour" and that everyone has personal Calvary, ascending to which it is possible to deserve an existential resurrection, is one of the most important tasks of the education system and one of the ways to overcome its disadvantages and eliminate the "meaninglessness of education".

\section{Conclusion}

Due to the contradictions between globalization and digitalization, the education system faces new challenges and complex problems. One of these problems is the existential aspect of a student's soul. Modern existentialism and literature devoted to this issue, including works by F.M. Dostoevsky, K. Hamsun, G. Márquez, and Ch. Aitmatov, can help solve the problem. However, the achievements in the field of existentialism cannot spontaneously be included in the structure of the education system. To introduce them, it is important to find a paradigm that unites all the existential aspects of a modern person. In our research, we considered the concepts of "Sisyphean hill", "Sisyphean labour", and "Road to Calvary" to be such paradigms. We believe that this approach is the most productive and optimistic and deserves to be creatively continued. 


\section{Acknowledgments}

The article is based on the results of research financially supported by the Financial University following a state assignment.

\section{References}

1. M.S. Ryumina, Ekzistentsialnyi krizis obrazovaniya v sovremennom obshchestve i perspektivy ego preodoleniya [Existential crisis of education in modern society and ways of overcoming it] (Science, Moscow, 2016)

2. S. Crowell, The Cambridge companion to existentialism (Cambridge Academy, Cambridge, 2012)

3. M. Gordon, The existentialist's survival guide: how to live truly in an inauthentic age (Harper Collins Publisher, New York, 2018)

4. T.M. Makhamatov, R.I. Polyakova, L.A. Balandina, N.M. Malyugina, E.V. Ganina, Revista Inclusiones, 7, 365-374 (2020)

5. V.V. Varava, Sedmoi den Sizifa: Esse o smysle chelovecheskogo sushchestvovaniya [The seventh day of Sisyphus: an essay on the reason for human being] (Rodina, Moscow, 2020)

6. J. Malpas, Existentialism as literature (Cambridge University Press, Cambridge, 2012)

7. S. Bakewell, At the existentialist café: freedom, being, and apricot cocktails (Chatto \& Windus Publisher, London, 2016)

8. T. Staehler, Existentialism: critical concepts in philosophy (Routledge, Taylor\&Francis, London, 2012)

9. T. Staehler, N. Martin, Existential aesthetics and philosophy of religion (Routledge, Taylor\&Francis, London, 2013)

10. T. Staehler, N. Martin, Horizons of existentialism (Routledge, Taylor\&Francis, London, 2013)

11. L.B. Omarova, A.M. Kalimullin, L.Y. Grudtsina, A.V. Korzhuev, M.Y. Zhukova, XLinguae, 11(3), 76-85 (2018)

12. A. Camus, Le mythe de Sisyphe. Essai sur l'absude [The myth of Sisyphus. Essay on the absurd], in Sumerki bogov [Twilight of the Gods], 222-318 (Politizdat, Moscow, 1989)

13. A. Steinbauer, Philosophy Now. Magazine of Ideas, 115(August/September), 11, (2016)

14. A. Camus, Sochineniya [Essays], Trans. from French (Politizdat, Moscow, 1990) 